\title{
A rare sighting of a bottlenose whale (Hyperoodon planifrons, Flower, 1882) in shallow waters off southeastern Brazil
}

\author{
Marcos César de Oliveira Santos*, Giovanna Corrêa e Figueiredo
}

Universidade de São Paulo.

(Laboratório de Biologia da Conservação de Mamíferos Aquáticos, Departamento de Oceanografia Biológica, Instituto Oceanográfico, Universidade de São Paulo, Praça do Oceanográfico, 191, Sala 145-A, Butantã, São Paulo, SP, Brasil. 05508-900.)

*Corresponding author: mcos@usp.br

Beaked whales belong to the family Ziphiidae (Cetartiodactyla, Odontoceti), which includes at least 21 described species worldwide (SHIRIHAI, 2006), representing almost one-quarter of all known living cetacean species. Usually found in deep waters beyond the continental shelf and remaining relatively little time at the surface, these species are still poorly known. On 27 April 2015 employees of the Port of Santos Maritime Department observed a live whale close to the shoreline ( $23^{\circ} 59.7^{\prime} \mathrm{S} ; 46^{\circ} 18.6^{\prime} \mathrm{W}$ ), in waters from 6 to $16 \mathrm{~m}$ deep. As it is not usual to record whales so close to the shore in the main entrance of the port of Santos, the crew approached and made a 2-minute video of the specimen using a smartphone. No additional sightings nor stranding events of elusive cetacean species which might have given clues as to the destiny of this specimen were detected in the area in the following days.

Based on the images recorded at distances ranging from 2 to $15 \mathrm{~m}$, it was observed that the whale was swimming slowly. During a period of 99 seconds, a total of 11 blows was recorded, with a sequence of 5 surfacing bouts in the first 33 seconds when the boat came very close, and three blows within a period of 8 seconds before the whale dived for the remaining 35 seconds prior to the end of the recording. Images showed part of the whale's body, from the forehead to the dorsal fin, closer glimpses of the forehead itself, its dorsum, the flukes from behind and the above-mentioned dive. These images allowed the authors to evaluate several details of the specimen's morphology and color patterns, which were used for the identification of the species as southern bottlenose whale, Hyperoodon planifrons. The clues used to identify the species were based on the descriptions found in LEATHERWOOD and REEVES (1983), MEAD (1989), SHIRIHAI (2006), VAN WAEREBEEK et al. (2005), BEST (2007) and
SANTORA and BROWN (2010). The characteristics observed were the following: (1) relatively large body estimated at 5 to $6 \mathrm{~m}$ long, (2) pale greyish coloration pattern (Figure 1), (3) extensive pale scars over the whole body, (4) large bulbous and pronounced forehead which was clearer than the rest of the body (Figure 2), (5) noticeable overhang of the melon over the proximity to the beak, (6) tall, sickle-shaped dorsal fin set far back on its body (Figure 3), (7) bushy blow projected forward (Figure 4), (8) and concave and unnotched flukes as commonly described for all ziphiids. In the present specimen, the slope of the forehead was steep and its surface flattened (Figure 3), which corresponds to the description given by GRAY (1883) in the light of the congener species from the Northern Hemisphere, the northern bottlenose whale, $H$. ampullatus.

When considering sightings of beaked whales in the Southern Hemisphere, it is not possible to exclude the possibility of misidentification with Arnoux's beaked whale (Berardius arnuxii) or Longman's beaked whale (Indopacetus pacificus) due to the difficulties encountered in identifying beaked whales in the wild (see MEAD, 1989; PITMAN et al., 1999; CLARKE, 2005; BEST, 2007), in addition to their prolonged dives, wariness of vessels, and limited distinguishing characteristics between ziphiid species (KASAMATSU; JOYCE, 1995). The posterior boundary of the pale melon extends backwards in the specimen observed (Figure 2), differently from that on $I$. pacificus in which this pattern of pigmentation stops at the blowhole (see PITMAN et al., 1999; VAN WAEREBEEK et al., 2005; BEST, 2007). Moreover, whilst Longman's beaked whale has a relatively large melon, it is not as bulbous as observed in southern bottlenose whales (MEAD, 1989; PITMAN et al., 1999; BEST, 2007). The shape of the dorsal fin in $H$. planifrons is strongly hooked 


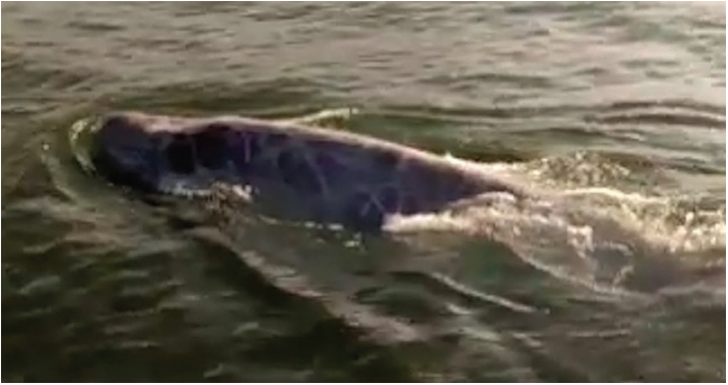

Figure 1. Southern bottlenose whale (Hyperoodon planifrons) sighted close to the main entrance of the Port of Santos, Brazil: details on pale gray color pattern and scars and scratches on its dorsum. Extracted from a smartphone video.

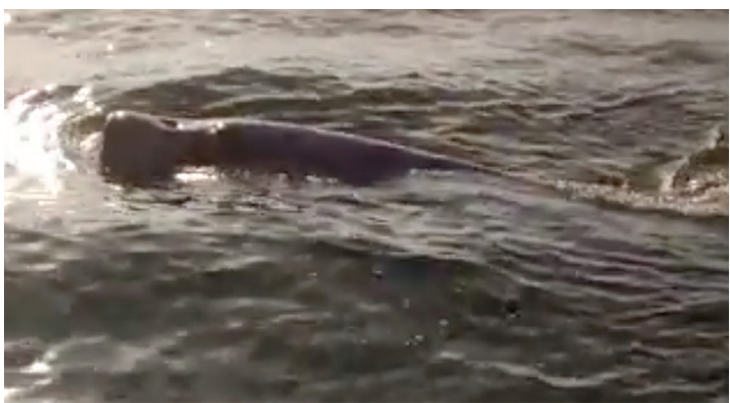

Figure 2. Detail of the bulbous and flattened forehead of a southern bottlenose whale (Hyperoodon planifrons) sighted close to the main entrance of the Port of Santos, Brazil. Extracted from a smartphone video.

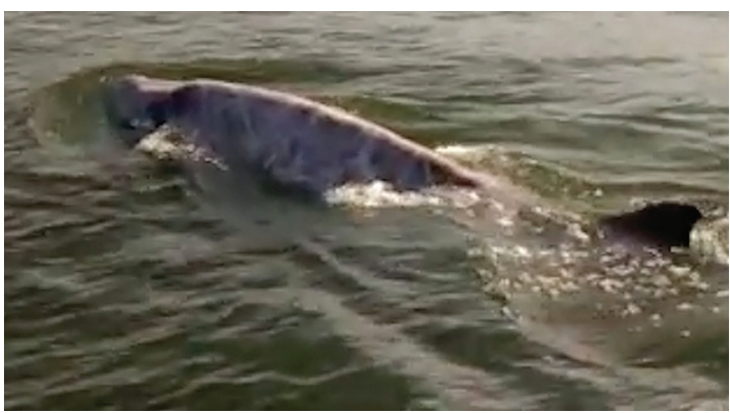

Figure 3. Details of the tall (in relation to its body), sickle-shaped dorsal fin set far back on the body of a southern bottlenose whale (Hyperoodon planifrons) sighted close to the main entrance of the Port of Santos, Brazil. Extracted from a smartphone video.

or pointed at the tip, falcate in shape (Figure 3), and more erect than that of $B$. arnuxii, which presents a relatively small dorsal fin in relation to its size, usually triangular or slightly rounded and falcate (PITMAN et al., 1999; SHIRIHAI, 2006).

As of 2014, less than 50 fresh specimens of southern bottlenose whales had been necropsied for scientific purposes, which represents a very small sample size on the basis of which to infer morphological characteristics

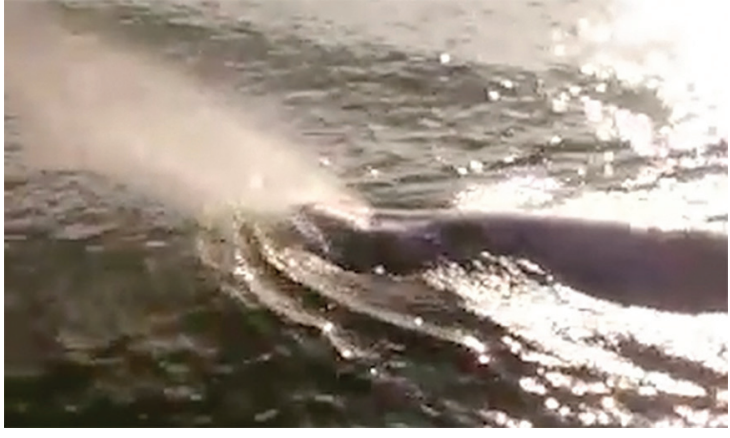

Figure 4. Bushy and forward blow of a southern bottlenose whale (Hyperoodon planifrons) sighted close to the main entrance of the Port of Santos, Brazil. Extracted from a smartphone video.

showing such clear sexual dimorphism as has been described for northern bottlenose whales (MEAD, 1989; BEST, 2007; GROOM et al., 2014). If the same patterns observed for $H$. ampullatus are applied to $H$. planifrons regarding sexual dimorphism, the estimated size, the pronouncedly whiter forehead, and the extensive area with scratches and scars with a whitish appearance on the top of its body are evidences that the individual sighted was a mature male (PITMAN et al., 1999; SHIRIHAI, 2006). Linear scars resembling tooth rake marks are usually indicative of adult males among beaked whales (see MACLEOD, 1998).

The specimen seemed to be emaciated, possibly unhealthy. It is likely that traveling in such shallow, coastal waters prevented this individual from having access to essential food intake. Based on the topography and bathymetry of the shoreline in southeastern Brazil, this sighting must be considered an unusual record. If a straight line is drawn to offshore waters, this specimen was sighted at least $225 \mathrm{~km}$ from the niches in which the species is usually found in higher latitudes, such as the deeper waters off the break of the continental shelf.

Southern bottlenose whales are known to have a circumpolar distribution in the Southern Hemisphere, south of $30^{\circ}$ S (FRASER, 1945; MEAD, 1989; GOWANS, 2002; TAYLOR et al., 2008). Stranded individuals have been reported at several sites in countries such as New Zealand (MCCANN, 1961), Australia, including Tasmania and the Heard Island (HALE, 1931; DAVIS; GUILER, 1984; DIXON et al., 1994; SLIP et al., 1995), South Africa (TIETZ, 1966; SEKIGUCHI et al., 1993), Chile (CLARKE, 1962), the Falkland Islands (HAMILTON, 1952; LICHTER, 1986; OTLEY et al., 2012), Tierra del Fuego (GOODALL, 1978; LICHTER, 1986; CLARKE; GOODALL, 1994) and Brazil (GIANUCA; CASTELLO, 
1976). This is the fourth known record of a bottlenose whale in Brazil. The first record occurred on 26 March 1975, near the border with Uruguay at $33^{\circ} \mathrm{S}$ (GIANUCA; CASTELLO, 1976). It was a $7.5 \mathrm{~m}$ long adult of unknown sex (MORG 0015) that may have, on the basis of the authors' description, been stranded for a month. The specimen is on exhibition in the cetacean hall at the "Museu Oceanográfico Professor Eliézer de Carvalho Rios". The second record was based on photographs of a stranded beaked whale notified on 5 May 1981 in Santa Catarina state at Praia do Rincão ( $28^{\circ} \mathrm{S}$ ) (CIMARDI, 1996). No skeleton remains are available. The third known record was presented in a manuscript reporting the first record of a Gray's beaked whale (Mesoplodon grayi) on the Brazilian coast (SOTO; VEGA, 1997). The authors updated beaked whale records for the country, inserting the information on the recovery of the left tympano-periotic bones and several vertebrae (MOVI 01874) attributed to a bottlenose whale found on 16 April 1993 close to the Mostardas lighthouse $\left(31^{\circ} \mathrm{S}\right)$. The record presented in São Paulo state is the first reported sighting of a bottlenose whale in Brazilian waters. In close proximity, PRADERI (1980) mentioned the stranding of a male bottlenose whale (RP 339) in February 1978 at Punta Artilleros, Colonia (ca. $\left.34^{\circ} \mathrm{S}\right)$, Uruguay. All these five records described in this paragraph were observed in lower latitudes from $23^{\circ} \mathrm{S}$ to $34^{\circ} \mathrm{S}$ and occurred between February and May. Based on the stranding records, we may speculate that southern bottlenose whales move northwards from the end of summer to autumn (March to May) in the Western South Atlantic.

Sightings of southern bottlenose whales have been described elsewhere (e.g. FINDLAY et al., 1992; KASAMATSU; JOYCE, 1995; KASAMATSU et al., 1998; SANTORA et al., 2010; SHEIDAT et al., 2011). Bottlenose whales have been classified as one of the most common ziphiid species in polar and subpolar waters, from $57^{\circ} \mathrm{S}$ to $70^{\circ} \mathrm{S}$, in summer (see KASAMATSU; JOYCE, 1995; SANTORA; BROWN, 2010; SHEIDAT et al., 2011). In waters deeper than $1000 \mathrm{~m}$, bottlenose whales have been sighted in December and January off Southern Africa $\left(>30^{\circ} \mathrm{S}\right)$, where they appear to be confined to the temperate and subtropical waters of the Agulhas Current in a marked seasonality (FINDLAY et al., 1992). Studies on ectoparasites and stomach remains have revealed that $H$. planifrons invest in seasonal movements between Antarctica and subtropical waters off Durban $\left(30^{\circ} \mathrm{S}\right)$, South Africa, with peaks in sightings recorded in February and October (SEKIGUCHI et al., 1993). A few prey items found in the stomachs of southern bottlenose whales have been assigned to the subtropical convergence in the Western South Atlantic (CLARKE; GOODALL, 1994), indicating the exploitation of different areas and reinforcing the possibility of venturing in latitudinal movements. The precise location where southern bottlenose whales may spend the winter remains a mystery though (FINDLAY et al., 1992; BEST, 2007). It seems that water temperature may not directly regulate these movements, but the life cycles of their food items, added to possible physiological constraints such as have been observed with regard to other cetacean species (see DURBAN; PITMAN, 2012) are likely to be the keys for further investigations.

The original description of the southern bottlenose whale was based on an imperfect and waterworn skull found on the Dampier Archipelago, northwestern Australia $\left(20.6^{\circ} \mathrm{S}\right)$ (FLOWER, 1882). It still remains the most northerly record for the species in the Southern Hemisphere (GROOM et al., 2014). Considering that the skull of the type specimen belonged to a stranded individual, together with another stranding reported in Namibia ( $\left.c a .23^{\circ} \mathrm{S}\right)$ in 1990 (quoted in BEST, 2007 as collected by the Whale Unit of the Mammal Research Institute of the University of Pretoria), and to the presented sighting in southeastern Brazil ( $\left.\mathrm{ca} .24^{\circ} \mathrm{S}\right)$, it seems that records in deep waters at latitudes lower than $30^{\circ} \mathrm{S}$ may not be considered unusual. Based on historical and updated stranding and sighting data, it is possible to infer that southern bottlenose whales may use warm temperate waters up to $20^{\circ} \mathrm{S}$ as suggested by MCCANN (1961). Dedicated research efforts in pelagic waters will certainly better improve our understanding of beaked whales' distributional range.

Ziphiids have been drawing researchers' attention to the main roles they may play within their range of distribution. For instance, oceanic squid species found in Antarctic, subantarctic and temperate deep oceanic waters with vertical distributions from 500 to $1000 \mathrm{~m}$ have been observed as the main prey items of southern bottlenose whales (SEKIGUCHI et al., 1993; CLARKE; GOODALL, 1994; SLIP et al., 1995; MACLEOD et al., 2003). In the Antarctic ecosystem, where bottlenose whales are known to be abundant and to forage on cephalopods (MACLEOD et al., 2003), which in turn are the major predators of krill (NEMOTO et al., 1985), they may play an important role as one of the main actors in a top-down regulation of the food web (HILL et al., 2007). If seasonal latitudinal 
movements of southern bottlenose whales effectively occur and they spend considerable time in distinct areas of the ocean basins, another important ecological role as vertical and horizontal vectors for nutrients should be attributed to these ziphiids (see ROMAN et al., 2014). Other studies on the feeding habits of $H$. planifrons have highlighted the importance of medium-sized odontocete cetaceans in all oceanic food webs where they may be considered the apex predators (KASAMATSU; JOYCE, 1995; SLIP et al., 1995).

Along the Brazilian coast, of a total of 46 cetacean species recorded, 9 have been Ziphiidae: B. arnuxii (SICILIANO; SANTOS, 2003), H. planifrons (GIANUCA; CASTELLO, 1976), Mesoplodon densirostris (CASTELLO; PINEDO, 1980), M. grayi (SOTO; VEGA, 1997), M. hectori (ZERBINI; SECCHI, 2001), M. europaeus (SANTOS et al., 2003), M. mirus (SOUZA et al., 2005), M. layardii (PINEDO et al., 2002) and Ziphius cavirostris (CARVALHO, 1969). They represent almost $20 \%$ of the reported cetacean diversity in Brazilian waters. The recent discoveries of a huge area with oil and gas reserves off the south and southeast coast of Brazil will demand decades of exploitation, and will certainly render economic profits counterbalanced by the cumulative impacts on the marine biota. These impacts on beaked whales must be monitored in order to evaluate their magnitude for future management plans. There is great concern as to the anthropogenetic impacts on beaked whales based on their sensitivity to loud sounds caused by naval sonar and seismic surveys, which may had led to atypical events of mass strandings where land was close to deeper waters (COX et al., 2006). This is not the case of the Western South Atlantic where cetacean mortality events in deep waters may have been under-reported because of the wide continental shelf.

\section{ACKNOWLEDGEMENTS}

The authors would like to extend their gratitude to Hermínio Conde Paz and Jorge de Moura of the Port of Santos's Maritime Department (PSMD) who shared the images gathered on the beaked whale and helped with additional information on the presented sigthting. The PSMD and the Instituto Oceanográfico da Universidade de São Paulo have a recently established partnership for the sharing of experiences to improve our knowledge on oceanographic issues regarding the São Paulo state coast. Leandro Inoe Coelho kindly processed the pictures presented, taken from a smartphone video. Salvatore Siciliano and Jarred Santora helped with the brainstorming necessary to reach the species identity. The authors dedicate this manuscript to the memory of Peter B. Best and Rae Natalie Prosser Goodall, whose contributions on the knowledge of cetaceans have inspired generations of scientists. The research on cetacean use of area and distribution along the coast of São Paulo state is financially supported by the Fundação de Amparo à Pesquisa do Estado de São Paulo (FAPESP) (Process 2011/51543-9). We thank the two anonymous reviewers who invested their time and efforts to evaluate this manuscript.

\section{REFERENCES}

BEST, P. B. Whales and Dolphins of the Southern Africa Subregion. Cambridge: University Press, 2007.

CARVALHO, J. P. Sobre a provável ocorrência da "baleia de Cuvier" no litoral de São Paulo. Rev. Nac. Pesca, v. 10, n. 82, p. 8-11, 1969.

CASTELlO, H. P.; PINEDO, M. C. Mesoplodon densirostris (Cetacea: Ziphiidae), primeiro registro para o Atlântico Sul Ocidental. Bol. Inst. Oceanogr., v. 29, n. 2, p. 91-94, 1980.

CIMARDI, A. V. Mamíferos de Santa Catarina. Florianópolis: FATMA, 1996. 302 p.

CLARKE, M. Whale observation and whale marking off the coast of Chile in 1958 and from Ecuador towards and beyond the Galapagos Islands in 1959. Norsk Hvalfangst-tid, v. 51, n. 7 , p. $265-287,1962$.

CLARKE, M.; GOODALL, N. Cephalopods in the diets of three odontocete cetacean species stranded at Tierra del Fuego, Globicephala melaena (Traill, 1809), Hyperoodon planifrons Flower, 1882 and Cephalorhynchus commersonii (Lacepede, 1804). Antarct. Sci., v. 6, n. 2, p. 149-154, 1994.

CLARKE, R. A southern bottlenose whale examined in the Antarctic. Lat. Am. J. Aquat. Mamm., v. 4, n. 2, p. 83-96, 2005.

COX, T. M.; RAGEN, T. J.; READ, A. J.; VOS, E.; BAIRD, R. W.; BALCOMB, K.; BARLOW, J.; CALDWELL, J; CRANFORD, T.; CRUM, L.; D'AMICO, A.; D'SPAIN, G.; FERANDEZ, A.; FINNERAN, J. J.; GENTRY, R. L.; GERTH, W.; GULLAND, F.; HILDEBRAND, J.; HOUSER, D.; HULLAR, T.; JEPSON, P. D.; KETTEN, D. R.; MACLEOD, C. D.; MILleR, P.; MOORE, S.; MOUNTAIN, D. C.; PALKA, D.; PONGANIS, P.; ROMMEL, S.; ROWLES, T. K.; TAYLOR, B.; TYACK, P. L.; WARTZOK, D.; GISINER, R. C.; MEAD, J. G.; BENNER, L. Understanding the impacts of anthropogenic sound on beaked whales. J. Cetacean Res. Manage., v. 7, n. 3, p. 177-187, 2006.

DAVIS, G.; GUILE, E. R. The occurrence of the southern bottle-nosed whale in Tasmanian waters. Proc. R. Soc. Tasmania, v. 118, p. 103-107, 1984.

DIXON, J. M.; FRIGO, L.; MOYLE, R. L. C. New information on the southern bottlenose whale, Hyperoodon planifrons (Cetacea, Ziphiidae), from a recent stranding in Victoria, Australia. Aust. Mammal., v. 17, p. 85-95, 1994.

DURBAN, J. W.; PITMAN, R. L. Antarctic killer whales make rapid, round-trip movements to subtropical waters: evidence for physiological maintenance migrations? Biol. Lett., v. 8, n. 2, p. 274-277, 2012. 
FINDLAY, K. P.; BEST, P. B., ROSS, G. J. B.; COCKCROFT, V. G. The distribution of small odontocete cetaceans off the coast of South Africa and Namibia. S. Afr. J. Mar. Sci., v. 12, n. 1, p. 237-270, 1992.

FLOWER, W. H. On the cranium of a new species of Hyperoodon from the Australian seas. Proc. Zool. Soc. Lond., v. 50, n. 3, p. 392-396, 1882.

FRASER, F. C. On a specimen of the southern bottlenosed whale, Hyperoodon planifrons. Discov. Rep., v. 23, p. 19-36, 1945.

GIANUCA, N. M.; CASTELLO, H. P. First record of the southern bottlenose whale, Hyperoodon planifrons, from Brazil. Sci. Rep. Whales Res. Inst., v. 28, p. 119-126, 1976.

GOODALL, R. N. P. Report on the small cetaceans stranded on the coasts of Tierra del Fuego. Sci. Rep. Whales Res. Inst., v. 30, p. 197-230, 1978.

GOWANS, S. Bottlenose whales Hyperoodon ampullatus and $H$. planifrons. In: PERRIN, W. F.; WÜRSIG, B.; THEWISSEN, J. G. M. (Ed.). Encyclopedia of marine mammals. San Diego: Academic Press, 2002. p. 128-129.

GRAY, D. Note on the characters and habits of the bottlenose whale (Hyperoodon rostratus). Proc. Zool. Soc. Lond., v. 50, n. 4, p. 726-731, 1883.

GROOM, C. J.; COUGHRAN, D. K.; SMITH, H. C. Records of beaked whales (family Ziphiidae) in Western Australian waters. Mar. Biodivers. Rec., v. 7, n. e50, 13 p., 2014.

HALE, H. M. Beaked whales - Hyperoodon planifrons and Mesoplodon layardii, from South Australia. Rec. S. Aust. Mus., v. 4, p. 291-311, 1931.

HAMILTON, J. E. Cetacea of the Falkland Islands. Com. Zool. Mus. Hist. Nat. Montevideo, v. 4, p. 1-6, 1952.

HILL, S. L.; REID, K.; THORPE, S. E.; HINKE, J.; WATTERS, G. M. A compilation of parameters for ecosystem dynamics models of the Scotia Sea-Antarctic Peninsula region. CCAMLR Sci., v. 14, p. 1-25, 2007.

KASAMATSU, F.; JOYCE, G. G. Current status of odontocetes in the Antarctic. Antarct. Sci., v. 7, p. 365-379, 1995.

KASAMATSU, F.; HEMBREE, D.; JOYCE, G.; TSUNODA, L.; ROWLETT, R.; NAKANO, T. Distribution of cetacean sightings in the Antartic, results obtained from the IWC/IDCR minke whale assessment cruises, 1978/791983/84. Rep. Int. Whaling Comm., v. 38, p. 449-487, 1988.

LEATHERWOOD, S.; REEVES, R. R. The Sierra Club Handbook of Whales and Dolphins. San Francisco: Sierra Club Books, 1983. 302 p.

LICHTER, A. A. Records of beaked whales (Ziphiidae) from the Western South Atlantic. Sci. Rep. Whales Res. Inst., v. 37, p. 109-127, 1986.

MACLEOD, C. D. Intraspecific scarring in odontocete cetaceans: an indicator of male "quality" in aggressive interactions? J. Zool., v. 44, p. 71-77, 1998.

MACLEOD, C. D.; SANTOS, M. B.; PIERCE, G. J. Review of data on diets of beaked whales: evidence of niche separation and geographic segregation. J. Mar. Biol. Assoc. U. K., v. 83, p. 651-665, 2003.

MCCANN, C. The occurrence of the southern bottlenosed whale, Hyperoodon planifrons Flower, in New Zealand waters. Rec. Dominion Mus., v. 4, n. 3, p. 21-27, 1961.

MEAD, J. G. Bottlenose whales Hyperoodon ampullatus (Forster, 1770) and Hyperoodon planifrons Flower, 1882. In: RIDGWAY, S. H.; HARRISON, R. (Eds). Handbook of marine mammals, volume 4: river dolphins and the larger toothed whales. London: Academic Press, 1989. p. 321-348.
NEMOTO, T.; OKIYAMA, M.; TAKAHASHI, M. Aspects of the roles of squid in food chains of marine Antarctic ecosystems. In: SIEGFRIED, W. R.; CONDY, P. R.; LAWS, R. M. (Eds.). Antarctic nutrient cycles and food webs. Berlin: Springer-Verlag, 1985. p. 415-420.

OTLEY, H.; SMITH, J.; DALEBOUT, M. L. Beaked whale strandings on the Falkland Islands and South Georgia, South Atlantic Ocean, between 1866 and 2008. J. Mar. Biol. Assoc. U. K., v. 92, n. 8, p. 1851-1864, 2012.

PINEDO, M. C.; BARRETO, A. S.; LAMMARDO, M. P.; ANDRADE, A. L. V.; GERACITANO, L. Northernmost records of the spectacled porpoise, Layard's beaked whale, Commerson's dolphin, and Peale's dolphin in the southwestern Atlantic Ocean. Aquat. Mamm., v. 28, n. 1, p. 32-37, 2002

PITMAN, R. L.; PALACIOS, D. M.; BRENNAN, P. L. R.; BRENNAN, B. J.; BALCOMB, K. C.; MIYASHITA, T. Sightings and possible identity of a bottlenose whale in the tropical Indo-Pacific: Indopacetus pacificus? Mar. Mamm. Sci., v. 15, n. 2, p. 531-549, 1999.

PRADERI, R. Addiciones a la lista sistemática de cetáceos del Uruguay. Res. Com. J. Cienc. Nat. Montevideo, v. 1, p. 136-137, 1980.

ROMAN, J.; ESTES, J. A.; MORISSETTE, L.; SMITH, C.; COSTA, D.; MCCARTHY, J.; NATION, J. B.; NICOL, S.; PERSHING, A.; SMETACEK, V. Whales as marine ecosystem engineers. Front. Ecol. Environ., v. 12, p. 377-385, 2014.

SANTORA, J. A.; BROWN, E. T. Spatial distribution patterns of southern bottlenose whales, Hyperoodon planifrons, near the South Shetland Islands, Antarctica. Mar. Mamm. Sci., v. 26, n. 4, p. 960-968, 2010.

SANTOS, M. C. O.; ZAMPIROLLI, E.; VICENTE, A. F. C.; ALVARENGA, F. Gervais' beaked whale (Mesoplodon europaeus) washed ashore in southeastern Brazil: extra limital record? Aquat. Mamm., v. 29, n. 3, p. 404-410, 2003.

SEKIGUCHI, K.; KLAGES, N.; FINDLAY, K.; BEST, P. B. Feeding habits and possible movements of southern bottlenose whales (Hyperoodon planifrons). Proc. NIPR Symp. Polar Biol., v. 6, p. 84-97, 1993.

SHEIDAT, M.; FRIEDLANDER, A.; KOCK, K. H.; LEHNERT, L.; BOEBEL, O.; ROBERTS, J.; WILLIAMS, R. Cetacean surveys in the Southern Ocean using icebreakersupported helicopters. Polar Biol., v. 34, n. 10, p. 1513-1522, 2011.

SHIRIHAI, H. A Complete Guide to Antarctic Wildlife: The Birds and Mammals of the Antarctic Continent and the Southern Ocean. Princeton: Princeton University Press, 2006.

SICILIANO, S.; SANTOS, M. C. O. On the occurrence of the Arnoux's beaked whale (Berardius arnuxii) in Brazil. J. Mar. Biol. Assoc. U. K., v. 83, n. 4, p. 887-888, 2003.

SLIP, D. J.; MOORE, G. J.; GREEN, K. Stomach contents of a southern bottlenose whale, Hyperoodon planifrons, stranded at Heard Island. Mar. Mamm. Sci., v. 11, n. 4, p. 575$584,1995$.

SOTO, J. M.; VEGA, S. S. Primeiro registro de baleia bicuda de Gray, Mesoplodon grayi Haast 1876, (Cetacea, Ziphiidae) para o Brasil, com referências osteológicas e a revisão de citações de zifídeos em águas brasileiras. Biociências, v. 5, n. 1, p. 69-89, 1997.

SOUZA, S. P.; SICILIANO, S.; CUENCA, S.; SANCTIS, B. A True's beaked whale (Mesoplodon mirus) on the coast of Brazil: adding a new beaked whale species to the Western Tropical Atlantic and South America. Lat. Am. J. Aquat. Mamm., v. 4, n. 2, p. 129-136, 2005. 
TAYLOR, B. L., BAIRD, R., BARLOW, J., DAWSON, S. M., FORD, J., MEAD, J. G., NOTARBARTOLO DI SCIARA, G.; WADE, P.; PITMAN, R. L. Hyperoodon planifrons. The IUCN Red List of Threatened Species. Version 2008.3. Downloaded on 25 May 2015.

TIETZ, R. M. The southern bottle-nose whale, Hyperoodon planifrons, from Humewood, Port Elizabeth. Ann. Cape Prov. Mus., v. 5, p. 101-107, 1966.
VAN WAEREBEEK, K.; FINDLAY, K.; FRIEDRICHSEN, G.; BEST, P. Bold colouration pattern in southern bottlenose whales, a preliminary assessment of external variation. IWC Scientific Committee Meeting, Ulsan, Korea, SC/57/SM 12, 2005, 9 p.

ZERBINI, A. N.; SECCHI, E. R. Occurrence of Hector's beaked whale, Mesoplodon hectori, in Southern Brazil. Aquat. Mamm., v. 27, n. 2, p. 149-153, 2001. 